\title{
IKKa modulates primary sclerosing cholangitis and intrahepatic cholangiocarcinoma
}

\author{
Qun Jiang ${ }^{*}$, Anthony J Scarzello, Zuoxiang Xiao, Timothy Back, Jami Willette-Brown, Feng Zhu, Yinling Hu, \\ Robert H Wiltrout
}

From Society for Immunotherapy of Cancer 29th Annual Meeting

National Harbor, MD, USA. 6-9 November 2014

Intrahepatic cholangiocarcinoma (ICC) is the second most common primary liver cancer after hepatocellular carcinoma (HCC). The risk of ICC is higher in patients with primary sclerosing cholangitis (PSC). To date, the cellular and molecular mechanism underlying the pathological progression of PSC and ICC is poorly understood. IKKa is part of the I $\kappa$ B kinase (IKK) complex, which plays an important role in regulating inflammation- associated carcinogenesis through both NF- $\kappa \mathrm{B}$-dependent and independent pathways. Here, we show that IKK $\alpha$ mutant mice developed very serious PSC as early as four weeks of age. The ALT/AST and bilirubin levels were significantly increased in the serum of IKK $\alpha$ mutant mice along with lymphocytic and eosinophilic infiltration into the liver. Liver inflammation in the IKK $\alpha$ mutant mice, mediated by macrophages, neutrophils and CD4 T cells, was associated with the death of cholangiocytes and hepatocytes, and obstruction of intrahepatic and extrahepatic bile ducts, which impeded bile flow and ultimately led to biliary fibrosis and cirrhosis. Additionally, upon activation of $\mathrm{NOTCH}$ signaling in the liver via hydrodynamic shear, we observed that NOTCH-induced ICC, with the PSC, developed significantly faster in IKK $\alpha$ mutant mice. To identify whether intrinsic IKK $\alpha$ dysfunction in hepatocytes promotes the $\mathrm{NOTCH}$-induced ICC in IKK $\alpha$ mutant mice, we generated IKK $\alpha$ hep KO mice, in which IKK $\alpha$ is conditionally knocked out in hepatocytes. No biliary disease or liver injury was observed in these mice. We then established an accelerated ICC model utilizing hydrodynamic delivery of NICD and AKT expression vectors. Unexpectedly, ICC development was remarkably slower in the IKKa hep KO mice compared to the IKKa floxed control mice, and this delayed ICC development was associated with reduced activation or levels of AKT, NOTCH, MAPK/Erk and

NCl-Frederick, MD, USA c-myc. These data suggest that IKK $\alpha$ may play a protective role in PSC, while promoting ICC derived from hepatocytes. In contrast to ICC, we also established the cMET/ $\beta$ catenin-induced HCC model in the IKK $\alpha$ hep KO mice, which did not reveal any difference in tumor development between IKK $\alpha$ hep KO and control mice. Taken together, our findings suggest that IKK $\alpha$ plays complicated and important roles in PSC and ICC pathological progression.

Published: 6 November 2014

doi:10.1186/2051-1426-2-S3-P171

Cite this article as: Jiang et al:: IKK $\alpha$ modulates primary sclerosing cholangitis and intrahepatic cholangiocarcinoma. Journal for ImmunoTherapy of Cancer 2014 2(Suppl 3):P171.

Submit your next manuscript to BioMed Central and take full advantage of:

- Convenient online submission

- Thorough peer review

- No space constraints or color figure charges

- Immediate publication on acceptance

- Inclusion in PubMed, CAS, Scopus and Google Scholar

- Research which is freely available for redistribution

Submit your manuscript at www.biomedcentral.com/submit C BioMed Central 